\title{
The emergent practice of governance and its implications for the concept of politics
}

Laurence Piper

School of Politics

University of KwaZulu-Natal

Private Bag X01

Scottsville

3209

piper@ukzn.ac.za

\begin{abstract}
This paper explores the implications of the disjuncture between the real-world practice of governance and the popular understanding of politics. There are two ways of addressing this disjuncture. The first is to accept the popular conception of politics and declare its relative decline, alongside the state, in the face of supra-national governance. The second is to challenge the popular conception of politics and include governance in a new, broader definition. Moving from the view that empirical social scientific concepts are judged in terms of their utility both to everyday discourse and to philosophical and theoretical discourses, a case is made for the second option.
\end{abstract}

Engaging with the theoretical tradition of 'politics as rule', it is argued that politics involves much more than coercive state power. Recent work affirms both the productive and positive-sum potential of power, including state power, and the wide variety of contexts in which power operates. Engaging with the theoretical tradition of 'politics as power', the costs of dissolving politics into power are highlighted. Consequently, politics is re-defined as the exercise of power in group decisionmaking. The emphasis on decision-making retains the historic association between politics and rule, while referring to 'group' rather than 'state' allows a broader conception of politics closer to the popular version. In addition, linking politics to decision-making affirms conscious choice and human agency, a methodological association important for the major empirical and normative theoretical traditions in Political Science.

\section{Introduction}

The advent of supra-national institutions like the European Union and the African Union, as well as common projects like the New Economic Plan for African Development (NEPAD), require that states 'pool' sovereignty, effectively ceding a degree of national sovereignty. These developments mark a qualitative shift in international relations marked by the rise of what is widely termed 'governance'. At the level of the state (Piper 2006, p. 146), governance introduces new forms of regulation which, although usually steered by government, have multiple sources of authority and produce a variety of types of rules. In so doing governance reconfigures the location of power from the state both 'upwards' in international and post-national ways, and 'downwards' in state-business partnerships to 'build the market' and statesociety partnerships to deliver services. The ethos of governance is inclusion and co- 
operation among a variety of role-players sharing a common goal. Governance also colonises new peoples in the developing world with typically technocratic understandings of democracy, markets and law. All of this makes governance a diffuse, complex, elite and technocratic co-operative enterprise.

The emergence of governance poses significant challenges for what most people regard as politics. This, I suggest, is 'partisan power struggles over power'. While the reasons for the emergence of this conception are even harder to identify than the conception, we can identify influences from the history of the idea of politics. From the theoretical tradition of 'politics as rule' we have inherited a notion of politics as about relations of conflict, and thus as a partisan, zero-sum game ultimately resolved by coercive force. On the other, from the tradition of 'politics as power' we have embraced the idea that politics is not just to be found in the state, but in any institution (United Nations, national cabinet), organisation (business, sports club) or group (local community, the family). The consequence has been to narrow the scope of what is considered politics while expanding the fields in which it is located. Thus at the same time as talking of politics in the workplace, the sports club, the family as well as the state, politics is limited to partisan power struggles.

Consequently, we are faced with a disjuncture between an emerging practice of governance and the popular understanding of politics. One way to resolve this disjuncture is to broaden our definition of politics to include the kind of activities captured by the concept of governance. Another is to define our according to the purpose they serve in everyday discourse. Against both views it is argued that the utility of social scientific concepts is twofold, and holds in respect of both practical and philosophical/theoretical discourse. In this instance, an argument is advanced in favour of politics as the exercise of power in group decision-making on both practical and theoretical grounds, particularly the theoretical traditions of 'politics as rule' and 'politics as power'.

Before making this case however, the disjuncture between the emerging practice of governance and the popular conception of politics is outlined, and the argument for the double accountability of empirical social science concepts is made.

\section{The rise of governance}

John Dunn (2000, p. 108) points out that the term 'politics' was not used in any known language a thousand years ago, but emerged later alongside the modern state. More specifically, 'politics' was associated with the new phenomenon of sovereign power in both practice and in theory. Thus, on the one hand, the state emerged as an institution with tremendous capacity to conduct war, collect taxes and enforce law, as well as assuming greater responsibilities of administration and welfare down time. On the other hand, as Skinner (1989, p. 115) notes, the idea of the state as the legitimate source of power was deployed to offset the competing notion of popular sovereignty.

In recent times the nature of state power has changed somewhat, not least in the emergence of the idea that state authority ought to rest with the people in the form of democratically elected government. However, growing popular power is only one way in which the sovereign power of the state has been challenged. One indicator of the changing character of state sovereignty is the emergence of a new term in political 
discourse: 'governance.' If government is associated with decision-making in a sovereign-state, governance emerged from the field of international relations as scholars grappled to understand rule-making in a context populated by many, and different kinds of, players without a clear hierarchy of authority (Rosenau 1995, pp. 4).

Simply put, the end of the cold war and especially the globalisation of financial markets and information systems have generated new kinds of post-national activities. In turn these require some kind of regulation to avoid crises like market crashes and international crime, but lack the 'vertically structured centres of power' that states traditionally enjoyed over their citizens (Langhorne 2001, p. 133). In this context regulation takes the form of the co-operative pursuit of norms and rules amongst multiple players, some of which are states, some of which are corporations, some of which are international organisations like the IMF and UN, but none of which has unambiguous authority over the others (Leonard 2005, p. 170). Consequently, this process is one that is 'steered' by various 'spheres of authority' rather than 'directed'. Further, it may well generate outcomes which are not legally binding.

Indeed, it is on the nature of the regulative outcome that Mörth (2004, p. 2) distinguishes government from governance. Where government formulates 'hard law', law that is legally binding and backed by sanction, governance generates soft law, which is not legally binding or enforceable but nevertheless has 'regulatory force'. Whether government and governance are distinguished in terms of the nature of the regulatory power, or the outcome of such regulation, or perhaps both, the distinction is made. Moreover, the distinction indicates an erosion of state sovereignty, mostly to the supra-national level.

Why the rise of governance? Two sets of reasons present themselves. First is that, as a consequence of globalisation the state has lost a degree of sovereignty over key aspects of social life. Central here is the emergence of the global economy although, as many note, not all aspects of the economy. Globalisation is mostly evident in the financial systems, notably investment and banking. Change has also come to a lesser extent in labour markets and trade. Perhaps just as important however, is the ideological hegemony of liberal-democratic capitalism as the global norm. All this has meant that states cannot, or choose not, to solve certain problems on their own, and co-operate with other states, and often international organisations, in addressing them. In sum the post-national character of some problems requires a shift from government to what Jacobsen (2004, p. 81) terms 'soft governance' - rules that emerge from negotiating voluntary learning and imposed pressures, a process Jacobsen describes as 'between deliberation and discipline'.

These developments are partly responsible for, and have been hastened by, the decline of the welfare state after World War II and the rise of neo-liberalism in the 1980s. However, as Loughlin (2004, pp. 8) notes, in recent times 'third way politics', now termed 'progressive governance', has replaced 'neo-liberalism' in many centre-left governments. Progressive governance looks to advance the objectives of the welfare state (social justice, freedom, equality) but in a pragmatic way that accommodates many neo-liberal economic requirements. Where welfarism affirms the state over the market and neo-liberalism the market over the state, 'third way' politics imagines a co-operative relationship between the two where the state is not reduced so much as 
better organised to help 'build markets'. This co-operative stance is generalised to other social domains where the state is supposed to play a steering role in partnership with other levels of government, the market and civil society in achieving 'good government' (ibid:21).

To this context one must add the dynamics of the developing world, and South Africa in particular. Many developing countries, especially African countries, find themselves in parlous economic situations, heavily dependent on international organisations like the IMF and World Bank and foreign companies for the financial investment required to grow their economies. Further, such support is usually conditional on recipient countries practising 'good government' which, as defined by the World Bank, essentially prescribes democracy, markets and the rule of law. Moreover, this triumvirate of virtues is operationalised in technocratic, procedural, ways. Democracy means regular, free and fair, multi-party elections; the rule of law, is outlined as democratic law presided over by an independent judiciary; and marketrelations are understood in the neo-liberal terms of free trade. As Thomas Weiss (2000, pp. 81) notes, the advocates of 'progressive governance', in particular sections of the UN, have tried to broaden the conception of good governance to include human rights, transparent public agencies, accountability for decisions by public officials, the devolution of resources and decision-making to local levels, and meaningful participation by citizens. Nevertheless, the emphasis on social and economic rights remains secondary, and the technocratic reading of democracy, markets and the rule of law largely unchallenged.

In sum then, the advent of 'governance' signals the rise of new practices in which authority is diffuse, processes complex, elites central and government technocratic, especially in the developing world. Clearly this has implications for the future of international relations and global politics, but our concern in this paper is more conceptual: the implications of governance for the concept of politics. That this ought to be a concern is reflected in the disjuncture between the practice of governance, and the popular conception of politics as partisan and ubiquitous conflict.

\section{Politics as partisan and ubiquitous conflict}

The claim that politics is widely conceived as partisan and ubiquitous conflict is challenging to sustain. Given its qualitative nature and the number of people in the world, the best that can be done under the circumstances is to examine the usage of the term 'politics' in public discourse and popular culture. Even then it is reasonable to assume that there will be many popular conceptions of politics. Nevertheless despite these challenges, I would hypothesise that it is reasonable to assume that one view will be more popular than the others, and that this view is that politics is partisan conflict over power, and that such conflict is endemic to most social relations.

I will illustrate this claim through a few (hopefully telling) examples from the public domain. Examples are deliberately identified at the supra-national, national and subnational levels so as to illustrate the differentiation between politics and rule in the popular mind. The first example concerns the recent self-assessment report submitted in mid 2006 by the South African government to the African Peer Review mechanism. The APRM is the mechanism to ensure good governance among African countries which are part of NEPAD. Bear in mind the process of compiling such a 
report is presented as a largely technical exercise of answering a set of questionnaires which operationalise 'good governance'. The APRM then sends a country review team which consults a wide range of stakeholders on the report. Notably, the Sunday Times (03/12/06) reported that the review team disagreed quite substantially with the South African government's own self-assessment. Top of the list of fifteen key threats to the stability of the South African economy was crime, which the report urged government make its top priority.

At one level this disagreement appears to be between the South African government and the APRM review panel, the latter comprising mostly academics, government officials and civil society leaders from elsewhere in Africa. On another level, the issue could be seen as party political given the ANC dominance of government and the way crime is used as an issue by opposition parties like the DA and ACDP to contest ANC power. Hence what was intended to be a mostly technical exercise now becomes a 'political' issue, that is, a source of partisan conflict, much to the discomfort of the APRM and South African government. This discomfort reveals that politics has taken on the meaning of 'partisan conflict' and that such conflict ought not to infringe on the inclusive, co-operative and technical nature of supra-national governance.

The idea that politics is both partisan conflict over power and also inappropriate for certain activities also applies at the level of the state. This much follows from the notions of an independent judiciary, an independent reserve bank and, in general, a system of public administration which serves all. To say that the any of these institutions has become politicised is to say that they now serve the particular interests of one party over others, and that this is inappropriate. The meaning of politics is thus narrowed to refer to partisan conflict with the perhaps paradoxical implication that there is ought to be 'no politics' in many important state functions.

However the idea of politics as partisan conflict is no longer just limited to the state or relations between states. Today the sites in which politics occurs are many. We talk of politics in sport, politics in the work-place, family politics, sexual politics, basically any group that is governed by rules or norms we now consider vulnerable to partisan forms of conflict. Hence to complain of sexual politics is to say, following Kate Millet, that men gain power over women via the act of sex. The idea of politics as partisan and involving struggle for power is now generalised to all corners of society.

The result is a conception of politics inconsistent with governance. The fact that governance is multi-authority sits awkwardly with the notion of politics as conflict over rule, more specifically, conflict associated with the state. Similarly the notion that governance produces 'soft' rather than 'hard' law rubs against statist forms of politics, as it is at odds with the notion of national sovereignty and the coercive backing this gives to law. Perhaps most significantly, the practice of governance is presented as incentive-driven, positive-sum and co-operative rather than coercive, zero-sum and conflictual. Lastly, the often technocratic attitude to the implementation of common goals eschews the partisan interpretation and practice associated with politics - where politics affirms difference, governance affirms conformity.

\section{Politics and the double accountability of social science concepts}


The literature on the concept of politics suggests two kinds of response to the disjuncture between concept and practice. The first, evident in Felix Oppenheim's (1981) Political Concepts, is to review, and usually broaden, the definition of a concept. Thus Oppenheim looks to 'construct a language of political enquiry that could be used by all political scientists regardless of their ethical or their ideological views' (in Morriss 1987, p. 199). A second approach, advanced by Peter Morriss in Power: A Philosophical Analysis is to choose concepts - not for their fit with a variety of theories - but for their utility in acting in the world. Hence, Morris (1987, p. 200) directly challenges Oppenheim for not asking why we need the concepts in the first place:

It is not a fruitful method of constructing anything to proceed in ignorance of what the thing is supposed to be for. If we want to choose (or construct) a knife we want to know whether it is to slice bread or spread butter with. People use knives for different reasons, and what knife-makers do not do is to come up with some neutral, all-purpose knife that is allegedly acceptable to all would-be knife users. The same applies to constructing a language.

Notably, Morriss' (1987, p. 201) objection does not rest on blurring the distinction between empirical description and normative judgement. He makes it very explicit that he is not claiming that empirical description is inherently normative. Thus the dispute does not centre on blurring 'is' and 'ought' as both Oppenheim and Morriss are committed to this distinction. Rather the dispute centres on whether concepts are better evaluated in terms of philosophical/theoretical coherence or practical utility. To my mind, both Oppenheim and Morriss err in being one-sided, as both ignore the fact that concepts are evaluated in terms of both kinds of criteria. This case will be made below, drawing on Anthony Giddens' arguments about the doubly hermeneutic character of social scientific concepts.

That philosophical/theoretical coherence matters for social scientific concepts is indubitable. Thus Dunn (2000, p. 12) observes that studying politics as the history of a word (concepts) inevitably intersects with studying politics as a history of ideas (conceptions). Further, these theories are intended to explain, and be judged by how well they explain the social world. As Rawls (1999, p. 3) states, 'a theory however elegant and economical must be rejected or revised if it is untrue'. Notably, such a claim applies to natural scientific concepts as well as social scientific concepts - until one takes account of Giddens' ‘double hermeneutic’.

Giddens (1984, p. 28) holds that social science has, as a field of study, 'phenomena which are already constituted as meaningful'. Indeed, to gain access to this world the social scientist must get to 'know what the actors already know, and have to know, to "get on" in the daily activities of social life'. Giddens further observes that the concepts social scientists invent are 'second-order' (or elite) in that 'they presume certain conceptual abilities on the part of the actors to whose conduct they refer'. But, he continues, it is in the nature of social-science that these can become appropriated within social life itself, and so become 'first-order' (or popular) concepts. In the natural sciences this does not happen. The behaviour of neither nor baboons is ever affected by scientific description. Giddens refers to the 'double' hermeneutic in that social concepts have two roles: they help constitute the frames of reference which agents use in daily life, and are also the interwoven into the theories used by social 
scientists. Thus the success and endurance of concepts relies on satisfying two constituencies pursuing two different activities: one analysing and interpreting social change using concepts and theory, and one acting in ways informed by concepts

In light of this it seems to me that there are two problems with the practical utility view advocated by Morriss. First, phenomenologically speaking, concepts are given as much as chosen, or at least given in the first instance. Hence, all of us always find ourselves in social relationships which we understand through language and various, perhaps poorly developed and contradictory, conceptions or theories of what society is and how it works. Given that we find ourselves in this condition, it seems empirically safe to infer that we inherit most of our concepts. To be sure we engage, reflect, adapt and perhaps abandon concepts as we find them philosophically problematic or practically useless, but we are always already conceptually and theoretically immersed as we enter society. A small example from Morriss above: assuming that the spreading of butter was a purpose of a knife developed after the cutting of meat, it appears that while the purpose of the butter knife, as well as its design, was different from the meat knife, it was nevertheless felt that that the concept of knife could be extended to cover this new purpose and design.

Indeed, this is probably the way most of our concepts evolve, and one of the reasons why social scientists and philosophers remain in demand: to sort out the theoretical and conceptual confusion that arises from social change. When Deleuze claims that the job of philosophers is 'forming, inventing, and fabricating concepts' (http://www.iep.utm.edu/d/deleuze.htm) he is probably singling out the rarest and most prestigious moment of the field of conceptual work, the work of the gloryseekers like Jamie Oliver who invent the 'flavour shaker' rather than the 'mixing bottle'. Hence, and this is the second point to be made to Morriss, the purpose of social concepts is always twofold: to assist in acting in the world and to assist in understanding the world. We do not do conceptual work only because it is useful to some real world activity (like the spreading of butter), but also because it is also important for our concepts and conceptions to obey the rules of reason and integrate with our broader conceptions of how the world works. Inevitably we also must clearly distinguish new conceptions (the butter knife) from existing ones (the knife), and relate these to an existing family of concepts (forks) and conceptions of how the world works (the role of cutlery). To put the point in Morriss' terms, the philosophical/theoretical coherence of our concepts is also a kind of utility.

To put the claim more sharply, we can only map successfully the fortunes of social scientific concepts in respect of both their intellectual and practical utility. When these reinforce each other, concepts come to be powerful. This explains the emergence and endurance the notion of 'sovereignty'. When slippage emerges between concepts as aids to understanding and to social activity then either concepts or practice must change. An example of the former is the term 'nation-state'. Today the vast majority of the world's states are substantially multicultural, and becoming more so, against the ethnic nationalism asserted and institutionalised in Europe in the nineteenth century. Faced with this reality the concept of nation-state has receded from political discourse and, conversely, the concept of 'multiculturalism' has arisen. An example of the latter is 'scientific racism', or at least the notion that racial difference is biologically determined, a theory which science has disproved but continues to live on in the popular mind, especially to justify racism. 
One claim of this paper is that the concept of politics faces the former kind of disjuncture between traditional conceptions or theories of what politics is, and contemporary practices summarised in the notion of 'governance'. The next section will outline these traditional conceptions of politics, and argue for an alternative conception of politics on grounds of both practical conceptual utility and philosophical/theoretical coherence.

\section{The history of the idea of politics: rule versus power}

The history of the idea of politics is one which yields of two main traditions: politics as about rule, and politics as about power. These traditions provides important resources for my argument that politics needs to redefined to include governance, and that such a redefinition is more useful than the popular view. More specifically it is shown that politics is better understood as about the exercise of power in group decision-making.

\subsection{Politics as Rule}

At the core of this view is the state is about rule, and that rule is, in the words of Finer, 'the regular exercise of ultimately coercive rule by some human beings over others'. Indeed, Dunn (2000, p. 15) holds that this remains 'the least controversial feature of this viewpoint'. Two important sub-points apply. First, although today politics today is an empirical concept rather than a normative one (despite the pejorative attitude most have towards conflict), this was not always the case for those who associated politics and rule. Indeed the conceptions of politics by Aristotle and Crick, which are also some of the most famous, are explicitly normative. Second, I argue that rule is to be distinguished from the modern state for although the exercise of coercive power is a key element of what the state does, and indicative of the social conflicts that make rule necessary, there are other things the state does, notably the administrative and welfare functions, which are some distance removed from conflict.

It is useful to begin with the normative account of politics by Aristotle as The Politics is the first work that explicitly uses the term 'politics'. Indeed, as Dunn (2000, p. 13) argues, reflecting on politics amounts to a struggle with Aristotle's ghost. In The Politics Aristotle is concerned with the problem of rule among free and equal human beings. At its best rule is the pursuit of the shared good for all citizens, such that humans who do not belong to such an association are sharply diminished by failing to do so (1962, p. 207). Notably, Aristotle picks out an association that is virtually selfsufficient, and identifies all of this with the Greek city state. Importantly, the ideal form of rule is not democratic, by which Aristotle saw a form of popular government by the poor over the rich, but a 'polity' in which the existence of a sizeable middleclass allows for the balancing of interests between rich and poor. In such a context, the practice of 'politics' means the participation of all citizens in deciding on, and acting for, the common good.

Politics then is a normatively rich concept for Aristotle, which becomes possible under conditions of minimised class conflict, and which is not orientated towards securing the purposes and interests of individuals or group but rather the purposes and interests of the community as a whole. Further, this pursuit requires the delicate 
balance between expertise and popular consent, the virtues of the aristocracy and the freedom of democracy, the artful resolution of which is the defining characteristic of practical wisdom. Importantly, for Aristotle the 'polity' is explicitly identified as but one of many forms of rule (monarchical, oligarchic, democratic), framed in terms of coercive power. Hence, in the background of his normative account of politics is a more general empirical conception of rule.

A similar normative conception of politics and background empirical conception of rule is evident in Bernard Crick's In Defence of Politics. Here Crick (1964, p. 18) argues that politics is the virtuous activity that looks to reconcile differences between plural groups by constructive dialogue and inclusion so that all can contribute toward the shared goal of social order. Unique to what today we might call plural democracies, politics is thus a constructive way of dealing with difference in the terms of the common good. In drawing this link between the common good and politics as virtuous practice Crick echoes Aristotelian themes. However, Crick's idea of what we are likely to think constitutes the common good is much narrower that Aristotle's, and more open to various forms of difference. Nevertheless, again one gets a sense of politics as the delicate art of balancing moderate social demands as against the struggles rooted in class conflict envisaged by Marx and feared by Mill.

Again, like Aristotle, in privileging politics as the right way to go about governing, Crick (1962, p. 27) also assumes the existence of various other forms of government, framed in more empirical terms as 'the organisation of a group of men in a given community for survival'. In a territorial society, he continues, government makes politics possible, but in international society politics has to try to make even minimal government or order possible. Thus, he concludes, 'where government is impossible, politics is impossible'. Instead (1962, p. 28) we have 'struggles for power'. On Crick's reading my above account of governance would amount to some kind of prepolitical, 'struggle for power'.

As already suggested, today Crick's views are not commonly held. Rather the common view of power as partisan conflict finds closer correspondence with Marx and Mill. For all their disagreement on the practice of economics and politics, Marx and Mill shared a remarkably similar conception of politics as rooted in the deep and conflicting interests of classes under capitalism. Indeed for Marx the advent of socialism spelt the death of both politics and the state. When the capitalist state, famously termed 'the executive committee for administering the affairs of the bourgeoisie', is swept away by revolution, an interim form of state, the dictatorship of the proletariat, is to be instituted until all the means of production are socialised, at which time the state will become unnecessary and 'wither away'.

While Marx's marginal regard for the state and politics is nothing less than stunning, Mill's conception of politics advocates a utilitarian role for the state in pursuing human happiness. More specifically, Mill believed that democracy would make people more active, more energetic and advance them 'in intellect, in virtue, and in practical activity and efficiency’ (in Macpherson 1977, p. 51). However, at the same time, he famously looks to limit the power of state and society over individuals in the name of individual freedom. This he does to prevent tyranny, especially tyranny of the majority, as even under a democracy minorities might find themselves oppressed for opposing the tide of popular opinion. More specifically, Mill lamented the division of 
society into two great classes with interests that conflicted so greatly, that democracy threatened to amount to the rule of one class over another. In order to protect the abuse of democracy in this way Mill proposed a system of plural voting such that the educated and wealthy had more votes than the poor. In sum, for Mill politics is underwritten by conflict and even the democratic state is laced with the threat of oppression.

As Dunn (2000, p. 32) argues, the links between politics and conflict remain powerful into the present, and probably into the future. Moving from the view that politics is concerned with rule, Dunn (2000, p. 49) argues that much of politics is defined by the nature of contemporary rule, and especially the state. Further, the nature of the modern state is contested with some seeing it primarily as a structure of elite domination while others see it as a means of solving co-ordination problems. Dunn (2000, p. 133) appears to lean towards seeing the state as a combination of both, although more about domination than the ideology of democracy suggests. This nevertheless still redeems the possibility that politics can be about co-operation and not just conflict, and in this regard Dunn specifically states that while human purposes have a tendency to conflict with each other, they are partially offset by a weaker propensity to co-operate. Further, he concludes that with globalisation (2000, p. 135) we have even more reason to assume that the struggles which result from the collisions between human purposes will continue into the future. Dunn's views affirm an empirical conception of politics largely, but not exclusively, associated with struggle and conflict. Gone is the notion of politics as Aristotle's practical wisdom, or Crick's inclusive pluralism. It is no longer a virtuous activity but one born of social, and perhaps natural, conflict. At the same time the state is redeemed as a key mechanism through which this conflict can be decided and, in some rare situations, constructively resolved.

These conceptions of politics and state are echoed in the mainstream accounts of liberal-democratic politics. Hence in Dahl's (1971) Polyarchy, which outlines the institutions of liberal-democracy, politics is understood in relation to a plurality of social groups (not just classes) contesting political office through elections to secure their ends. The possibility of the state pursuing the common good is not excluded from this view, but it is not assumed in the design of the system nor in the attitude of the citizenry. Rather the system moves from view of politics as market-place, with citizens using their currency to acquire the politicians they desire - echoing Macpherson's (1977, p. 77) characterisation of contemporary democracy as an 'equilibrium model'.

\section{2 'Politics as rule' and the alternative concept of power}

As noted above, the concept of politics emerged alongside the modern state, and is strongly associated with national sovereignty, more specifically the ultimately coercive power that defines 'rule'. What are we to make of this legacy? Clearly, it is indubitable that 'rule' remains in the world; that it remains overwhelmingly still associated with the state; and that this is likely to endure for some time into the future. It is also the case that the popular conception of politics as partisan conflict reflects the liberal-democratic 'equilibrium' model that is the global norm. Thus rule is legitimated in terms of party competition for government which then is free to deploy the state to ends within the limits sets by liberalism and capitalism. However, as the 
arguments concerning governance suggest, the erosion of national sovereignty has implications for the policies and laws adopted by participating states, especially those states who find themselves as part of the European Union, but to some degree for all states who participate in supra-national political processes. It also has implications for characterising the nature of what I would like to use politics.

The fundamental point is that even if 'rule' remains definitively associated with the state, the exercise of coercive power is increasingly a diminishing part of liberaldemocracy. To be sure, coercion matters in respect of war and in relation to crime. However, not only is there much less war than one hundred years, this fact is closely associated with the rise of liberal-democracy. It remains a remarkable fact that no two liberal democracies have ever gone to war with each other. Further, much of what passes for war nowadays does not have the national character it used. A moment's reflection on the growing significance of international initiatives of peace-keeping and now peace-making, and the multinational character of the 'coalition' in the Iraq war, suggests that coercion is taking increasing supra-national form around a common commitment to liberal-democratic capitalism.

More importantly, if one examines the functions of the contemporary liberaldemocratic state in terms of where it spends its money and deploys its personnel (education, health, welfare, market support) then it becomes abundantly clear, with the possible exception of the USA, that the administrative and welfare role of the state is now most of what the state does. Indeed, following Galbraith's (1983, p. 2-6) account of the instruments of power as including condign (coercive), compensatory (resource) and conditioned power (belief), the latter two are much more central to the activities of the contemporary state than coercion. Simply put, the state gets its way through the deployment of resources and persuasion rather than coercion. To put the point another way, if politics is mostly associated with the activities of the state, and if the activities if the state are better perceived through the concept of power rather than coercion, as seems to be the case, then perhaps politics is better understood in power terms.

Furthermore, it is also clear that the exercise of power can be detected in a range of other social contexts outside of the state. Usually these are organisational or institutional settings concerned with making decisions for a group like a corporation. However, this need not be the case. There may be settings where the existence of an organisation or institutions is in doubt. One possible case might be the family. A more compelling example might be some more spontaneous decision-making process like a popular revolt. If what singles politics out is the exercise of power in making a decision for a group then it is possible to accommodate this kind of event.

So far my argument holds for the popular version of politics (partisan and ubiquitous conflict) as much as for my proposed alternative (exercise of power in group decisionmaking). However, I would suggest that in respect of theories of 'politics as rule' my proposed version outperforms the popular definition in retaining a link to decisionmaking, and is therefore closer to the historical association between politics, the state and 'rule'. This is because decision-making, commonly viewed as choosing between various options, not only captures much of what governments do in initiating law, developing policy, going to war, and so on, but places choice at the heart of politics. 
In contrast, by casting politics as partisan conflict over power the popular conception not only extends the sites for politics to any in which power is exercised, but it breaks the link between politics and choice. This pulls the popular concept of politics even further away from 'rule' and the state but, perhaps more importantly, it also promises to dissolve politics into power altogether, robbing us of a language to single out the deliberate contest/co-operation around choices that consumes so much of our energy.

\subsection{Politics as Power}

The 'politics as power' tradition was spawned from the debates on the nature of American politics in the 1960s. On one side of the debate were the 'elite theorists' who held that American democracy was, in reality, dominated by a small elite, and on the other were the pluralists who held that different groups alternated in political office. The elite theorist view was most famously articulated by C. Wright Mills in The Power Elite. Here Mills (1956, p. 3-4) argued that America was a society dominated by a small group; a society in which, despite the formal trappings of liberal democracy and freedom, a power elite were in command:

They run the big corporations. They run the machinery of the state and claim its prerogatives. They direct the military establishment. They occupy the strategic command posts of the social structure, in which are now centred the effective means of the power and the wealth and the celebrity which they enjoy.

On this view, the link between politics and the state was less important than the links between politics and power as it was one group who was exercising power in political, economic and cultural domains simultaneously. It was in response to arguments of this type that Robert Dahl, and other 'pluralists' including Polsby and Wolfinger, embarked on a ranged of empirical studies examining decision-making in local communities. These studies found that different actors and different interests groups prevailed in different 'issue-areas' e.g. health or education at different times and places. This led them to conclude that, overall, there was no 'power elite' and that power was distributed 'pluralistically' in the system. In sum, they saw the diversity of winners on different issues as redeeming the effectiveness of American democracy.

Notably, in arguing against the elite theorists, the pluralists often embraced the same conceptual view that politics was about power. Hence in Who Governs? (2005, p. 16) Dahl embraces the common conception of power as defined by Max Weber which he defines as 'A has power over B to the extent that A can get B to do something $\mathrm{B}$ would not otherwise do'. Dahl applied his definition(s) of power in Who Governs?, his famous study of politics in the city of New Haven, by examining which participants 'had initiated alternatives that were finally adopted, had vetoed alternatives proposed by others, or had proposed alternatives turned down' (2005, p. 336). These actions were then counted as successes or defeats, and those with most successes deemed the most powerful. In short, politics is understood from the perspective of the exercise of power.

For Lukes, Dahl's conception of power is flawed in linking power too closely to the presence of conflict. Indeed he notes instances in Who Governs? when Dahl himself appears sensitive to the operation of power in the absence of overt conflict. Thus Dahl 
(2005, p. 66) writes that 'a rough test of a person's overt or covert influence is the frequency with which he successfully initiates an important policy over the opposition of others, or vetoes policies initiated by others, or initiates a policy where no opposition appears' (italics added). For Lukes this is just but one of several examples where the text of Who Governs? is more subtle and profound than the formal methodology of Robert Dahl.

A further revision of the concept of power and its implications for politics emerges in the work of Bachrach and Baratz (1970, p. 7). These scholars argue that, in addition to the first dimension of power (or 'face' of power a they call it), 'power is also exercised when A devotes his energies to creating or reinforcing social and political values and institutional practices that limit the scope of the political process to public consideration of only those issues which are comparatively innocuous to A'. This, they add, A might do 'consciously or unconsciously'. This conception of power is broader than Dahl's in that it extends power-relations beyond the scope of formal decision-making and observable conflict to include those exercises of power where A controls the agenda of politics precisely to prevent public conflict with B. This implies that power, and politics, can involve more than observable conflict between the preferences of agents involved decision-making; it can also include the ways in which decisions are prevented from being taken on potential issues. For Bachrach and Baratz we can identify such potential issues in terms of grievances which may be overt, that is already articulated in the decision-making system, or covert, that is only expressed outside the decision-making system.

For Lukes, this view of power is a significant advance on the pluralist conception, but does not go far enough. At the core of Luke's objections is the claim that power exists by influencing people's wants. Indeed, he (1974, p. 28) observes 'is it not the supreme and most insidious exercise of power to prevent people, to what ever degree, from having grievances by shaping their perceptions, cognitions and preferences in such a way that they accept their role in the existing order of things, either because they can see or imagine no alternative to it, or because they see it as natural and unchangeable, or because they value it as divinely ordained and beneficial?'. It is in response to these kind of problems that Lukes proposes his 'third dimension' concept of power. This is summarised in the formula: A exercises power over B when A affects B in a manner contrary to B's interests.

As Lukes acknowledges in the second edition of PRV (PRV2) this definition of power is too narrow as power is more than domination, indeed power 'over others' can, at times, be a positive phenomenon. Hence (2005, p. 65) he revises his definition to read something akin to: 'A exercises power over B when A affects B's interests either positively or negatively'. By affirming the positive moment to 'power over', Lukes compensates for a glaring omission, made most famously by Foucault in his various accounts of power, as well as dealing with the problem of unintended consequences in PRV.

The second advantage of Lukes' account is the scope of the definition of power which he claims can accommodate the preceding definitions of power in that the term 'interests' is interpreted by liberals and reformists such that they reduce to preferences and grievances respectively. Hence Lukes (1974, p. 37-8) says: 
...different conceptions of what interests are associated with different moral and political positions. Extremely crudely, one might say that the liberal takes people as they are and applies want-regarding principles to them, relating their interests to what they actually want to prefer... The reformist, seeing and deploring that not everyone's wants are given equal weight by the political system, also relates their interests to what they want to prefer, but allows that this might be revealed in more indirect and sub-political ways... The radical however, maintains that people's wants may themselves be a product of a system which works against their interests, and, in such cases, relates the latter to what they would want and prefer, were they able to make the choice.

In sum, Lukes' conception of power is not simply an alternative for radicals, but an alternative consistent with several major theories. As I will argue below, this move is instructive for how to proceed in respect of the dilemma of the disjuncture between the popular concept of politics and the phenomenon of governance.

\section{4 'Politics as power' and the alternative concept of politics}

Lukes' definition of power has two distinct advantages over its rivals. The first is that it can be used to explore the ways that power-relations are 'conditioned' or 'practiced' rather than simply intended. In so doing it opens the possibility of thinking about power as a system in which agents play out roles, the full effects of which they may not comprehend. Clearly such a conception of power is deeply attractive to many Marxist, feminist, indeed even nationalist, accounts of power-relations faced with the problem of the compliance of the oppressed to domination. Of course as Tilley (1991) points out there are many, less radical, and probably more common reasons why domination persists, including covert rebellion, the multiple and contradictory interests of subordinates, sufficient reward from the system, and the high costs of resistance. What Lukes helps with are forms of domination sustained by ignorance and mystification, by some systematic miscomprehension of the way the world works.

It is not difficult to see that this kind of radical critique might have some purchase on the discourse of governance, more specifically, if politics and governance are maintained as separate concepts. At first glance this popular distinction seems attractive. Not only is this distinction consistent with common usage of politics (and perhaps over time of governance too), but they appear to pick out different kinds of activities. We are familiar with politics as the partisan, usually party, struggle for power, whereas governance captures the sense of technical pursuit of a collective end captured in the notion of public administration. The problem however, as pointed out by radical social theorists, is the way this terminology facilitates the ideological character of rule. Simply, put, terminology like administration and governance provide a language which allows for the presentation of particular (class, gender, race, elite) interests to present themselves as general, or to present political (partisan) questions as technical. Marxists offer instances of both in, firstly, Marx's account of ideology, and second, contemporary critique of neo-liberal economics as governed by scientific rules.

Further, such concealment of partisan agendas or interests has real implications for social relations, not least as democracy under liberal-capitalism is limited to the realm of politics as partisan conflict. We do not get to elect our judges, senior civil servants, 
the reserve bank chairman, nor are the processes of decision-making in these institutions democratic. While I am not of the view that all processes of social decision-making ought to be democratic, the more the pursuit of purposes and satisfaction of interests is rendered 'non-political', the less power ordinary people have. There is something suggestive in the fact that Al-Qaeda bombed business and military buildings in 9-11, but not democratic institutions. Is this indicative of where real power is perceived to lie? And if so, do we not facilitate our further disempowerment by allowing a discursive creep that removes elite interests and purposes from democratic contest, and legitimates this in the name of expert knowledge and the common interest? In short, perhaps the discourse of governance, and especially good governance, is simply a façade to facilitate increasing elite and partisan power. Clearly one can remain agnostic on this specific analysis whilst preferring a conceptual scheme that kept the possibility of such an analysis alive.

Two more points: first, the recognition that power is not necessarily only about conflict resonates with the presentation of governance as inclusive, incentive-driven co-operation around common goals. This is a major way in which the alternative conception of politics sets itself out from the popular conception. Notably, the distinction here refers to the underlying theory of politics behind these two definitions as superficially they do not differ in respect of using the word power. However, the concepts behind the word are quite different in each case. Effectively we are able to return to a concept of politics which is open to notions of the common good and to virtuous practice following Aristotle, while retaining its current associations with partisan conflict.

Second, by specifically linking politics to the exercise of power in decision-making, the alternative definition avoids dissolving politics into power, which it might otherwise do. If politics is just the exercise of power, then the difference between politics and power becomes the difference between power as capacity and its exercise. This move would both frustrate an important practical discursive need and colonise family discourses. Defining politics in terms of power alone dissolves the historical association between politics and the state into a broader social landscape. Politics as a vocation, and political science as a discipline, are premised on the assumption that decision-making, especially the formal mechanisms by which this happens, are important and worthy of attention. Whether at international, state or local level, or in any organisation, we want a discourse to talk about decision-making. If politics not longer picks these out, then another concept or other concepts (like government or governance) must take its place, as in the work of Aristotle and Crick.

Conversely, blurring power and politics threatens related discourses and concepts that engage with power relations outside of group decision-making. Simply put all social relations become political relations, with some affront to the sociologist, cultural theorist, anthropologist and economist. It is one thing to say that politics, understood as a process of decision-making, inheres in all collectives including business and the family; it is another to say that all power relations (economic, social and cultural) are just as easily termed 'political'. Lastly, the definition of politics as just power requires re-evaluating fundamentally the methodologies as well as the content of political analysis and action away from a focus on conscious choice to more oblique processes of preference formation. Just as all social science becomes Political Science, all Political Science becomes social science. 
Further the focus on politics as the exercise of power in group decision-making implies a process of conscious choice, thereby affirming a clear link between politics and human agency. In so doing, it opens the way for forms of normative advocacy associated with modern values. Linking politics to decision-making, and thus choice, allows normative argument about importance of publicity for a free, just and democratic social order, on almost all theories whether liberal, Marxist, republican, pluralist or deliberative. Modern political thought is run through with affirmations of publicity or transparency, implicated as these are in the particular conceptions of human subjectivity and the consensual basis of a just and legitimate social order that most of us embrace. While defining politics independently of conscious choice is not by itself a denial of such normative views, the implicit link between publicity and politics is broken. In a small way the work of the liberal/Marxist/republican/pluralist/deliberative advocate is undone. Lastly, linking politics to decision-making does not deny the possibility of radical analyses of powerrelations, but recognises that the very act of examining such relations brings them to consciousness and so 'politicises' them.

\section{Conclusion}

Less than 100 years after its zenith the 'nation-state' has all but passed away, and 'multiculturalism' has emerged in its wake. Is something similar happening to the sovereign state with the growth of supra-national governance? If so, what does this mean for the concept of politics given its long association with the state? That 'politics' may be irrelevant to governance is reflected in the diversion between the popular conception of politics as partisan conflict over power, and the characterisation of governance as inclusive co-operation over common objectives. My view is that there is good reason to rescue the concept of politics by broadening it to include governance. Simply put, we need a conception of politics as the exercise of power in group decision-making.

This argument draws on a methodology for conceptual change that is broader than that typically used in the literature on power. Against the views that concepts are to be assessed primarily in terms of utility to theory (Oppenheim) or utility in practice (Morriss), it is held that concepts must satisfy the demands of both theory and practice. This follows Giddens' account of the 'doubly hermeneutic' character of social scientific concepts. Consequently, it is held that the alternative conception of politics must be - and is - superior on both theoretical and practical grounds.

Theoretically, the alternative definition of politics places group decision-making at its centre, thus forging a stronger link with the tradition of 'politics as rule' than the popular account. It picks out conscious contest (and sometimes cooperation) over collective problems from this tradition. At the same time, the revised conception looks to broaden the conception of politics beyond the state, and beyond 'rule' understood as coercive power. This is because most of what states do is somewhat removed from coercion, and is better captured by the concept of power. Further, the exercise of power in decision-making is not always conflictual or harmful, and is evident in many groups other than the state. 
Practically speaking, politics as the exercise of power in decision-making is superior to the popular view in that it enables us to characterise as 'political' forms of cooperation such as governance. By drawing a clear distinction between politics and a revised Lukesian conception of power through the emphasis on decision-making, much of the ordinary use of the term politics is preserved. In this way the concept of power is kept consistent with core methodologies and theories of Political Science, without cost to radical analysis as power-relations can still become 'politicised' by being brought into the group decision-making process.

\section{References}

Aristotle. 1992. The Politics. London: Penguin.

Bachrach, P. and Baratz. M. 1970. Power and Poverty: Theory and Practice. New York: Oxford University Press.

Crick, B. 1962. In Defence of Politics. Harmondsworth: Penguin.

Dahl, R. 1961, 2005. Who Governs? Democracy and Power in an American City Second Edition. New Haven and London: Yale University Press.

Dahl, R. 1971. Polyarchy: Participation and Opposition. New Haven \& London: Yale University Press.

Dunn, J. 2000. The Cunning of Unreason: Making Sense of Politics. London: Harper Collins.

Galbraith, J.K. 1983. The Anatomy of Power. London: Hamish Hamilton.

Giddens, A. 1984. The Constitution of Society. Cambridge: Polity.

Hamilton, LA. 2003. The Political Philosophy of Needs. Cambridge: Cambridge University Press.

Jacobson, K. 2004. 'Between Deliberation and Discipline: Soft Governance in EU Employment Policy’ in Mörth, U. (ed). 2004. Governance and Regulation: An Interdisciplinary Analysis. Cheltenham: Edward Elgar.

Langhorne, R. 2001. The Coming of Globalization: Its Evolution and Contemporary Consequences. Basingstoke, Palgrave.

Leonard, E.K. 2005. The Onset of Global Governance: International Relations Theory and the International Criminal Court. Aldershot: Ashgate.

Loughlin, J. 2004. 'The Transformation of Governance: New Directions in Policy and Politics', Australian Journal of Politics and History 50(1), 8-22.

Lukes, S. 1974. Power A Radical View. London: Macmillan.

Lukes, S. 2005. Power A Radical View. Second Edition. London: Palgrave. 
Macpherson, C.B. 1977. The Life and Times of Liberal Democracy. Oxford: Oxford University Press.

Mills, C.W. 1956. The Power Elite. Oxford: Oxford University Press.

Morriss, P. 1987. Power: A Philosophical Analysis. Manchester: Manchester University Press.

Mörth, U. 2004. 'Soft Law in Governance and Regulation: An Interdisciplinary Analysis in Mörth, U. (ed) Governance and Regulation: An Interdisciplinary Analysis. Cheltenham: Edward Elgar.

Oppenheim, F. 1981. Political Concepts: A Reconstruction. Oxford: Blackwell.

Piper, L. 2006. 'Beyond neo-liberalism; beyond the ANC: South African politics as "progressive governance"' in Marcus, T. and Hofmaenner, A. (eds.) Shifting the Boundaries of Knowledge: A view on Social Sciences, Law and Humanities in South Africa. Pietemaritzburg: University of KwaZulu-Natal Press.

Rawls, J. 1993. A Theory of Justice. Revised edition. Cambridge, Mass.: Belknap.

Rosenau, J.N. 1995. 'Governance in the Twenty-First Century', Global Governance. 1(1), 3-15.

Skinner, Q. 1989. 'The State' in Ball, T., Farr, J. and Hanson, R. (eds). Political Innovation and Conceptual Change. Cambridge: Cambridge University Press.

Tilley, C. 1991. Domination, Resistance, Compliance... Discourse', Sociological Forum 6(3), $593-602$.

Weiss, T.G. 2000. 'Governance, good governance and global governance: conceptual and actual challenges', Third World Quarterly 21(5), 795-814. 